\title{
A!
}

This is an electronic reprint of the original article.

This reprint may differ from the original in pagination and typographic detail.

Scherleitner, Moritz

The Imported Mismatch Rule in Light of the Fundamental Freedoms

Published in:

INTERTAX: INTERNATIONAL TAX REVIEW

Published: 01/01/2021

Document Version

Peer reviewed version

Please cite the original version:

Scherleitner, M. (2021). The Imported Mismatch Rule in Light of the Fundamental Freedoms. INTERTAX:

INTERNATIONAL TAX REVIEW, 49(5), 391-405.

https://kluwerlawonline.com/journalarticle/Intertax/49.3/TAXI2021039

This material is protected by copyright and other intellectual property rights, and duplication or sale of all or part of any of the repository collections is not permitted, except that material may be duplicated by you for your research use or educational purposes in electronic or print form. You must obtain permission for any other use. Electronic or print copies may not be offered, whether for sale or otherwise to anyone who is not an authorised user. 
Summary:

While it is not what the drafters of BEPS Action 2 and, thereupon, Article 9 of the ATAD wanted to see, some differences between Member States' application of the anti-hybrid rules have been spotted or are to be expected. Thus, the national implementation of the Imported Mismatch Rule contained in Article 9(3) of the ATAD can be triggered with respect to intra-EU payments. Against this background, the author analysed the Imported Mismatch Rule in light of the fundamental freedoms.

Key words:

Imported Mismatch, Hybrid Mismatch, ATAD, ATAD II, EU Tax Law, Anti-Hybrid, Private Equity, Fund

\section{The Imported Mismatch Rule in Light of the Fundamental Freedoms}

\section{Moritz Scherleitner*}

\section{A Question that Should Not Be Asked}

In writing his doctoral thesis, ${ }^{1}$ the author concluded that there is no need to analyse the Imported Mismatch Rule included in Article 9(3) ${ }^{2}$ of the updated ${ }^{3}$ Anti-Tax Avoidance Directive (ATAD) from the perspective of the fundamental freedoms. ${ }^{4}$ The reason for abstaining from inquiring into this issue lays in the freedom of establishment being relevant ${ }^{5}$ and it not being possible for this rule to apply in intra-EU situations. After all, the ATAD must be implemented by all Member States, and rules as technical as those included in Article 9 of the ATAD should not leave room for deviations. ${ }^{6}$ In particular, based on recital 28 of the second Anti-Tax Avoidance Directive (ATAD II), ${ }^{7}$ Member States should use the applicable explanations and examples in the 454-page OECD Report on BEPS Action $2^{8}$ 'as a source of illustration or interpretation to the extent that they are consistent with the provisions of this Directive and with Union law'.

Assuming that the hybrid mismatch rules included in the ATAD are interpreted and applied in a uniform manner, the Imported Mismatch Rule can only deny deductions for payments that directly or indirectly fund a hybrid mismatch ${ }^{10}$ (hereinafter 'Imported Mismatch payment' and are made to third countries. Payments made to a recipient in the EU, on the other hand, should not trigger the rule either because this Member State has

\footnotetext{
* Moritz Scherleitner, LL.D., MSc. (WU), post-doctoral researcher at the University of Helsinki, Faculty of Law; affiliated with PwC Finland. The author thanks Prof. Marjaana Helminen and Linda Sydänmaanlakka for discussing a draft version of the article and two unknown peer reviewers for their comments. In addition, the author thanks Suomen veromiehet - Finlands beskattningsmän ry for their financial support. All possible errors are solely the author's who can be contacted at Moritz.scherleitner@helsinki.fi.

${ }^{1}$ M. Scherleitner, Addressing Tax Arbitrage with Hybrid Financial Instruments: A Multidisciplinary Study and Proposal for Developed and Developing Countries, Doctoral Series Vol. 54, sec. 5.5.3.2. (IBFD 2020).

${ }^{2}$ The Imported Mismatch Rule reads: 'A Member State shall deny a deduction for any payment by a taxpayer to the extent that such payment directly or indirectly funds deductible expenditure giving rise to a hybrid mismatch through a transaction or series of transactions between associated enterprises or entered into as part of a structured arrangement except to the extent that one of the jurisdictions involved in the transaction or series of transactions has made an equivalent adjustment in respect of such hybrid mismatch.' See OECD, Neutralising the Effects of Hybrid Mismatch Arrangements - Action 2: 2015 Final Report, OECD/G20 Base Erosion and Profit Shifting Project, 83-91 and 341-422 (OECD Publishing, 2015) [hereinafter OECD BEPS Action 2].

${ }^{3}$ Council Directive 2017/952 of 29 May 2017 amending Directive (EU) 2016/1164 regarding hybrid mismatches with third countries, OJ L 144/1, 1-11 (7 June 2017) [hereinafter ATAD II].

${ }^{4}$ Council Directive 2016/1164 of 12 July 2016 laying down rules against tax avoidance practices that directly affect the functioning of the internal market, OJ L 193/1 (19 July 2016) [hereinafter ATAD].

${ }^{5}$ See Scherleitner, supra n. 1, at sec. 5.5.3.2.

${ }^{6}$ An exception applies with respect to certain financial instruments with conversion, bail-in, or write-down functions. This is mainly relevant in the banking sector and shall be left out of scope in this article.

${ }^{7}$ ATAD II.

${ }^{8}$ OECD BEPS Action 2, supra n. 2.

${ }^{9}$ Recital 28 ATAD II.

${ }^{10}$ In the sense of Art. 9(1)-(2) ATAD.
} 
neutralized the mismatch between itself and another state (hereinafter 'direct mismatch') ${ }^{11}$ or because this Member State has itself neutralized the mismatch imported from a third state. ${ }^{12}$

As section 2 will demonstrate, it can no longer be refrained from investigating the Imported Mismatch Rule from the perspective of the fundamental freedoms on the same grounds as the author did. Differences in the implementation of the ATAD have already been spotted, and more are likely to come. After briefly discussing some examples and, notably, ignoring nuances that impact the whole discussion, the author analyses the Imported Mismatch Rule from the perspective of the freedom of establishment in section 3.

\section{The Imported Mismatch Rule in the EU}

Once (even slight) differences between Member States' implementation and interpretation of Article 9 of the ATAD exist, it is possible that the Imported Mismatch Rule applies. All that is needed is that one Member State does not regard a certain transaction to fall under its anti-hybrid rules while the other involved Member State does. Predictably, it is those somewhat vague elements of Article 9 that can effectuate these differences.

The most obvious example is the structured arrangements rule. Even though the OECD tried to provide specific guidelines as to what is to be considered a structured arrangement ${ }^{13}$ and thus fall within the scope of BEPS Action 2 (and, by extension, should guide the interpretation of Article 9 of the ATAD), ${ }^{14}$ it is natural that the required case-by-case analysis has a potential to create disagreement. If a Member State does not neutralize a direct mismatch that another Member State would have neutralized, payments from the latter to the former Member State can fall within the scope of the Imported Mismatch Rule. As a consequence, the deduction would be denied to the extent that it is set off against the mismatch.

Another concept that is likely to trigger the Imported Mismatch Rule is the 'acting together' rule. ${ }^{15}$ This is a provision of high importance in fund structures. ${ }^{16}$ Under BEPS Action 2, as explicitly underlined in Example 11.5., it is the common management of an investment partnership that leads to all partners being regarded as acting together. In effect, this means that each investor is deemed to hold as much as the fund itself holds in a target company. ${ }^{17}$ As the vehicles used in an investment fund context can very well trigger hybridity, it is not surprising that jurisdictions with a large private equity market consider reactions to avoid - in their view undesirable consequences. ${ }^{18}$ Luxembourg, for instance, introduced a safe harbour rule that, in essence, deems investors holding less than $10 \%$ in the fund of not acting together unless proven otherwise. Investors holding more than $10 \%$, on the other hand, are considered as acting together. ${ }^{19}$ In effect, this means that the scope of the hybrid mismatch rule is opened under the 'acting together' rule (only) once those holding more than $10 \%$ hold more than $50 \%$ in the fund. ${ }^{20}$ Whether this is ultimately in line with the ATAD is seen differently in

\footnotetext{
${ }^{11}$ Based on Art. 9(1)-(2) ATAD. See, for a discussion, e.g. B. Peeters \& L. Vanneste, The Hybrid Financial Instruments: The Effects of the OECD BEPS Action 2 Report and the ATAD, 48(1) Intertax 14-45 (2020); L. Mechtler, Hybrid Mismatches im

Ertragsteuerrecht (LexisNexis 2017); L. Parada, Double Non-taxation and the Use of Hybrid Entities: An Alternative Approach in the New Era of BEPS (Kluwer 2018); or D. Smit, The Anti-Tax-Avoidance Directive (ATAD), in: European Tax Law sec. 12.4.4. (P. Wattel, O. Marres \& H. Vermeulen eds., Wolters Kluwer 2019).

${ }^{12}$ Based on Art. 9(3) ATAD.

${ }^{13}$ OECD BEPS Action 2, supra n. 2, at 105-113.

${ }^{14}$ Recital 28 ATAD II.

${ }^{15}$ See OECD BEPS Action 2, supra n. 2, at Art. 11.3, Recommendation 11.3.

${ }^{16}$ See also, e.g. T. Cabollet, The Impact of ATAD 2 on Real Estate and Private Equity Funds, 21(3) Derivs. \& Fin. Instrums. sec. 4.2., (2019).

${ }^{17}$ Thus, due to the fund holding 100\% in A Co., every investor (regardless of his holding in the fund) is regarded as holding $100 \%$ in A Co. for the purposes of the anti-hybrid rules. Hence, every single one can cause a hybrid mismatch that is within the personal scope of the rules. This is because, under this rule, each investor is treated as holding the interests of other investors. See OECD BEPS Action 2, supra n. 2, at 453-454, Example 11.5.

${ }^{18}$ See, broadly, e.g. L. Sheppard, Anticipating EU Tax Haven Hybrid Rules, Tax Notes Intl. 1217 (2019).

${ }^{19}$ See, for a description and references to underlying Luxembourg law, e.g. O. Hoor, Luxembourg Implements ATAD 2 (Part 1), Bloomberg Tax (20 Sept. 2019), available at https://news.bloombergtax.com/daily-tax-report-international/insight-luxembourgimplements-atad-2-part-1 (accessed 26 Sept. 2020).

${ }^{20}$ With respect to Hybrid Financial Instruments, the required threshold is $25 \%$. See ibid.
} 
literature. ${ }^{21}$ From the perspective of this article, it actually does not matter; rather, what counts is that other Member States may refer to Example 11.5 provided in BEPS Action 2 when interpreting the 'acting together' rule. When they do so, they only look at the participation of the fund in an entity and nothing else. This can, again, easily trigger the Imported Mismatch Rule in this Member State because there may be a corporate platform that makes a deductible payment to another EU holding company, e.g. a Luxembourg company held by the fund vehicle which, itself, may be debt-financed by the fund vehicle. ${ }^{22}$

Furthermore, it is even possible that there are several layers of EU group companies in other Member States between the Member State that did not neutralize a mismatch and the Member State that applies the Imported Mismatch Rule. Finland, for instance, does not apply the Imported Mismatch Rule to intra-EU transactions. ${ }^{23}$ This is based on the assumption that it cannot be triggered in this context. ${ }^{24}$ While it is, in terms of policy, understandable to provide for such a simplification, it is not precisely what the ATAD foresees. Another Member State might not have such a carve-out and may apply the Imported Mismatch Rule to payments that are imported from another Member State into its territory through Finland.

\section{Compatibility with the Freedom of Establishment}

\subsection{The Right Perspective}

Before entering into the analysis, it is necessary to put the question into the right perspective. In fact, when assessing the implementation of secondary EU law in light of primary EU law, it makes a difference as to whether a measure in an area that is exhaustively harmonized at the EU level is at stake. ${ }^{25}$ Under these circumstances, the European Court of Justice (ECJ) tends to adopt a more lenient approach when assessing the provision under primary EU law. ${ }^{26}$ The focus is instead on analysing the national rule in light of the harmonized EU law. ${ }^{27}$ Stated differently, in such a context, the ECJ does not, in the first place, question whether Member States went too far but rather asks whether they went far enough. ${ }^{28}$ On the other hand, in so far as the underlying secondary EU law does not constitute an exhaustive harmonization, the national implementing legislation is analysed based on regular ECJ case law. ${ }^{29}$

Pursuant to Article 3 of the ATAD, the directive constitutes a minimum standard. Thus, Member States can provide for stricter rules. To the extent that they do so, they act in an area that has not been exhaustively harmonized. This means that the traditional ECJ doctrine on the interpretation of the fundamental freedoms is relevant. ${ }^{30}$ However, different considerations apply with respect to the minimum standard itself because, in

\footnotetext{
${ }^{21}$ Regarding the practice being in line with the ATAD, see, e.g. T. Lesage, S. Richard \& F. Salentiny, Implementation of ATAD 2 in Luxembourg and Implications For Alternative Investment Funds, Tax Notes Intl. 1135, 1144 (2020). For those expressing doubts, e.g. representatives of the Irish Revenue, see Sheppard, supra n. 18, at 1221.

${ }^{22}$ In more detail on ATAD II in a private equity context, see, e.g. Cabollet, supra n. 16; and R. Bolwerk, T. Cabollet \& J. Elink Schuurman, Hybrid mismatches - ATAD 2 secs. 2.6.1.2.2., 4.6. (Wolters Kluwer 2020).

${ }^{23}$ FI: Laki eräiden rajat ylittävien hybridijärjestelyjen verotuksesta, 1567/2019, §8.

${ }^{24}$ FI: Hallituksen esitys eduskunnalle laiksi eräiden rajat ylittävien hybridijärjestelyjen verotuksesta ja siihen liittyviksi laeiksi, HE 68/2019vp, 86.

${ }^{25}$ See, in more detail in the context of the ATAD, Smit, supra n. 11, sec. 12.3.

${ }^{26}$ See, e.g. PL: ECJ, 7 Mar. 2017, Case C-390/15, Rzecznik Praw Obywatelskich (RPO), ECLI:EU:C:2017:174, para. 54, stating, including further references: ' $[\mathrm{I}] \mathrm{t}$ is understood that, when the EU legislature adopts a tax measure, it is called upon to make political, economic and social choices, and to rank divergent interests or to undertake complex assessments. Consequently, it should, in that context, be accorded a broad discretion, so that judicial review of compliance with the conditions set out in the previous paragraph of this judgment must be limited to review as to manifest error.' See ibid., at sec. 12.3, as well as, e.g. J. Hey, Europäische

Steuergesetzgebung - Binnenmarkt und Fiskalinteressen, in: Europäisches Steuerrecht 30 et seq. (M. Lang ed., DStJG Tagungsband 2018); and D. Ehlers, § 7 Allgemeine Lehren der Grundfreiheiten, in: Europäische Grundfreiheiten und Grundrechte para. 9 (U. Becker \& D. Ehlers eds., de Gruyter 2009).

${ }^{27}$ E.g. Smit, supra n. 11, at sec. 12.3; C. Brokelind \& P. Wattel, Free Movement and Tax Base Integrity, in: European Tax Law sec. 15.2. (B. Terra \& P. Wattel eds., vol. 1 Wolters Kluwer 2019).

${ }^{28}$ As concisely formulated by Brokelind \& Wattel, supra $\mathrm{n}$. 27, at 655.

${ }^{29}$ Smit, supra n. 11, at sec. 12.3, with reference to NL: ECJ, 18 Sept. 2003, Case C-168/01, Bosal Holding BV,

ECLI:EU:C:2003:479, para. 26. See further, e.g. Brokelind \& Wattel, supra n. 27, at sec. 15.2.

${ }^{30}$ See Smit, supra n. 11, at sec. 12.3 .
} 
this regard, exhaustive harmonization occurred. ${ }^{31}$ Consequently, when analysing the relevant national implementation of the Imported Mismatch Rule, the interpreter will also have to assess whether and to what extent the rule goes beyond the minimum standard included in Article 9(3) of the ATAD. As the details are still to be determined and as national implementation may diverge in this regard, ${ }^{32}$ the author will limit himself to a general analysis of the Imported Mismatch Rule in light of the ECJ's regular case law.

As a result, the approach of this analysis may be more critical than the approach of the ECJ when it comes to the actual test of the relevant national rules. In this regard, it should be noted that more permissive access of the ECJ to the Imported Mismatch Rule - or, in fact, to the whole ATAD - would also not be without reason: the ATAD, as well as all other direct tax directives, is based on Article 115 of the Treaty on the Functioning of the European Union (TFEU). This requires unanimity in the council that, in direct taxation matters, is notoriously difficult to achieve. ${ }^{33}$ On the other hand, judicial self-constraint should also not go too far. After all, the requirements for creating primary EU law are higher than the requirements of Article 115 of the TFEU especially because, in the former setting, national parliaments are directly involved as well. ${ }^{34}$ This matters especially in the context of secondary EU direct tax law that has frequently been criticized for its lack of democratic legitimization. ${ }^{35}$ Apart from that, scholars have recently called upon the ECJ to act as the taxpayers' advocate in a battle against a 'cartel' of fiscal authorities who have, through the ATAD, just sharpened their swords in fighting a common antagonist. ${ }^{36}$ The ECJ should be reluctant in doing away with longstanding principles to align with the current political agenda. ${ }^{37}$ Notably, the court is well able to show its teeth when required. In Verkooijen (C-35/98), for instance, the court fended off Member States' attempts to uphold their discriminatory corporate tax systems by including Article 65(1)(a) in the TFEU. ${ }^{38}$ The article is even part of primary EU law, and while caution must be used to not extrapolate this judgment too far beyond its context, it still shows that Member States may cross the line by undermining overarching EU principles. ${ }^{39}$

\subsection{Discrimination or Restriction}

In order for there to be an infringement of the freedom of establishment, it has to be determined whether the Imported Mismatch Rule constitutes a forbidden discrimination or restriction. ${ }^{40}$ In this context, a comparability analysis is necessary. Treating cross-border situations worse than domestic situations does not violate EU law if, in light of the object and purpose of the relevant law, the situations are not comparable. ${ }^{41}$

In his thesis, ${ }^{42}$ the author held that, with respect to direct mismatches caused by the different treatment of payments under financial instruments, the comparability will depend on whether the ECJ is prepared to take

\footnotetext{
${ }^{31}$ See ibid.

${ }^{32}$ To give an obvious example, Member States may interpret the term 'structured arrangement' more strictly, i.e. as covering more cases than what is found in the ATAD. Ownership thresholds may also differ. Yet, the Imported Mismatch Rule is rather mechanical and, as such, room for Member States' leeway is limited.

${ }^{33}$ Brokelind \& Wattel, supra n. 27, at 655-657. Compare, e.g. P.K. Schmidt, A General Income Inclusion Rule as a Tool for Improving the International Tax Regime - Challenges Arising from EU Primary Law, 48(11) Intertax sec. 3.2.4. (2020).

${ }^{34}$ E.g. Hey, supra n. 26, at 30 et seq. See further the Estonian General Court case, EE: GC, 2 Oct. 2009, Case T-324/05, Republic of Estonia v. European Commission, ECLI:EU:T:2009:381, para. 208; or NL: ECJ, 5 May 1982, Case C-15/81, Gaston Schul Douane Expediteur BVv. Inspecteur der Invoerrechten en Accijnzen, Roosendaal, ECLI:EU:C:1982:135, para. 42, as referred to in CFE ECJ Task Force, Opinion Statement ECJ-TF 2/2018 on the ECJ Decision of 7 September 2017 in Eqiom (Case C-6/16), Concerning the Compatibility of the French Anti-Abuse Rule Regarding Outbound Dividends with the EU Parent-Subsidiary Directive (2011/96) and the Fundamental Freedoms, 58(10) Eur. Taxn. sec. 4, footnotes 49, 51 (2018) for references to ECJ case law in which a more generous approach is followed. The latter is regarded to be more typical.

${ }^{35}$ See, e.g. F. Vanistendael, EU Elections and EU Taxation, Tax Notes Intl. 729, 732 (2015).

${ }^{36}$ W. Schön, Interpreting European Law in the Light of the OECD/G20 Base Erosion and Profit Shifting Action Plan, 74(4/5) Bull. Intl. Taxn., (2020).

${ }^{37}$ Ibid., at secs. 6.4.3., 7.

${ }^{38}$ DE: ECJ, 6. June 2000, Case C-35/98, Staatssecretaris van Financiën v. B.G.M. Verkooijen, ECLI:EU:C:2000:294, para. 44 et seq. See Hey, supra n. 26, at 26 for the reference.

${ }^{39}$ Compare on this issue Hey, supra n. 26, at 26.

${ }^{40}$ See, e.g. M. Helminen, EU Tax Law sec. 2.2., 2.2.5. (IBFD 2020); or, in detail, J. Englisch \& E. Reimer, Diskriminierungs- und Beschränkungsverbote im direkten Steuerrecht, in: Europäisches Steuerrecht (H. Schaumburg \& J. Englisch eds., Otto Schmidt 2020).

${ }^{41}$ E.g. Helminen, supra n. 40, at sec. 2.1.3.1.

${ }^{42} \mathrm{See}$, with plenty of further references, Scherleitner, supra $\mathrm{n} .1$, at sec. 5.5.2.1.
} 
into account the tax treatment at the level of the receiver. If it does, it could be argued that the less favourable treatment of the cross-border situation is not comparable to the domestic situation because, in a domestic situation, such a mismatch based on the different tax treatment of payments is not possible. ${ }^{43}$ However, this is not the typical perspective of the ECJ; it rather normally looks at the domestic company alone. ${ }^{44}$ Still, based on Schempp (C-403/03), some authors have argued that the ECJ could be willing to take such an 'overall view'. ${ }^{45}$ After all, at stake was a linking rule that applied between (then) unrelated taxpayers, namely in respect of alimony payments from a German resident to his Austrian ex-wife. The payments were exempt in Austria and, therefore, not deductible in Germany while they would have been deductible if they had been taxed in Austria. Based on that, the ECJ held that the payments to Austria were not comparable to payments made to German recipients. ${ }^{46}$ Yet, others have been hesitant to extend this judgment to anti-hybrid rules. ${ }^{47}$ Apart from the judgment having been subject to harsh critique in literature and confirmation of this in later jurisprudence appearing absent, ${ }^{48}$ it may also make a difference that, in Schempp, an individual was involved while antihybrid rules only apply to corporations. The payments in Schempp did not belong to a business. The payments covered by the anti-hybrid rules, on the other hand, clearly do.

It could be argued that, in the context of the Imported Mismatch Rule, the case for denying comparability becomes even smaller compared to the direct mismatch rules. Ultimately, the counterparty (and, potentially, the counterparty's further counterparties) should be fully taxed on the income. Thus, a successful extension of the Schempp logic to the Imported Mismatch Rule would require the ECJ to disregard the entity or entities in between. However, the author would also not rule out that the ECJ takes such a perspective. After all, the comparability analysis happens against the background of the object and purpose of the rule at stake, ${ }^{49}$ and the object and purpose of the direct mismatch rules are not conceptually different from the object and purpose of the Imported Mismatch Rule. Thus, if the ECJ is prepared to adopt an overall view in the context of the direct mismatch rules, it may also adopt an overall view in the context of the Imported Mismatch Rule. Ultimately, there is a connection between the payment subject to the Imported Mismatch Rule and the mismatch that occurs between two different taxpayers. Yet, as explained in more detail below, the quality of this connection can vary more strongly in the context of the Imported Mismatch Rule. ${ }^{50}$ This could again impact the outcome of the comparability analysis.

\footnotetext{
${ }^{43}$ To be clear, that does not mean that a deduction/non-inclusion result is impossible in a domestic setting. Yet, should it occur, it is unlikely to be caused by the different treatment of the payment (even though OECD BEPS Action 2, supra n. 2, at 213-214, Example 1.13 seems to include such an instance). Rather, it seems more likely to be caused by the status of the taxpayer, i.e. it being taxexempt.

${ }^{44}$ See, e.g. M. Helminen, EU Law Compatibility of BEPS Action 2: Neutralising the Effects of Hybrid Mismatch Arrangements, 60(3) Brit. Tax Rev. (2015); and the further references provided for in Scherleitner, supra n. 1, at footnote 2272.

${ }^{45}$ See, e.g. C. Kahlenberg \& N. Vogel, Unionsrechtsvereinbarkeit der durch Korrespondenzregeln ausgelösten Ungleichbehandlung? Eine Untersuchung des BEPS-Aktionspunkts 2, StuW 294-299 n. 3 (2016); and R. de Boer \& O. Marres, BEPS Action 2: Neutralizing the Effects on Hybrid Mismatch Arrangements, 43(1) Intertax sec. 5.2. (2015).

${ }^{46}$ DE: ECJ, 12 July 2005, Case C-403/03, Egon Schempp v. Finanzamt München, ECLI:EU:C:2005:446, paras. 33-35.

${ }^{47}$ Mechtler, supra n. 11, at 140-145, 170; and, similarly, but with different arguments, J. di Maria, Comparability in the case of Hybrid Mismatch: In Search of an Approach Suitable for the Current European Landscape, in: Non-Discrimination in European and Tax Treaty Law 79-81, 85-86 (K. Dziurdź \& C. Marchgraber eds., Linde 2015). See, e.g. Helminen, supra n. 44, at 330; and C.H.J.I. Panayi, The Compatibility of the OECD/G20 Base Erosion and Profit Shifting Proposals with EU Law, 70(1/2) Bull. Intl. Taxn. sec. 3., (2015).

${ }^{48}$ See, e.g. Scherleitner, supra n. 1, at footnote 2283, with reference to M. Lang, Das EuGH-Urteil in der Rechtssache SchemppWächst der steuerpolitische Spielraum der Mitgliedstaaten?, 15(9) SWI, (2005); R. Mason, A Theory of Tax Discrimination, NYU Jean Monnet Working Paper No. 09/06, 46-49 (2006); and, including further references, C. Marchgraber, Tackling Deduction and Non-Inclusion Schemes - The Proposal of the European Commission, 54(4) Eur. Taxn. sec. 6., (2015); Di Maria, supra $\mathrm{n} .47$, at 7981; and Mechtler, supra n. 11, at 143. See also the discussion in C.H.J.I.

Panayi, The Schempp Case: EU Citizenship, Rights and Taxes - A New Leaf in ECJ Jurisprudence or Just a Fig Leaf?, 45(11) Eur. Taxn., (2005).

${ }^{49}$ See, e.g., including further references, FI: ECJ, 8 Nov. 2012, Case C-342/10, Commission v. Finland, ECLI:EU:C:2012:474, para. 36; and, very recently, Advocate General Hogan, Case C-480/19, Request for a preliminary ruling from the Korkein hallinto-oikeus (Finland), lodged on 24 June 2019.

${ }^{50} \mathrm{See}$, in more detail, the discussion and references in secs. 3.2.3-3.2.4, as well as the discussion in Scherleitner, supra n. 1, at sec. 5.4.5.
} 
What remains is the full or partial denial of the deduction of a payment made to a foreign related party while such a payment to another domestic company would remain deductible ${ }^{51}$ Even though this is always connected to more favourable tax treatment elsewhere, ${ }^{52}$ and noting that precisely this is meant to promote the Internal Market, ${ }^{53}$ it is, nevertheless, possible that the ECJ regards this as a restriction that, in order to be permissible, needs to be justified by an overriding reason of public interest. On the other hand, if the court, based on argumentation along the lines of section 3.3.3, were to not regard the Imported Mismatch Rule as creating a restriction, the examination would stop here. ${ }^{54}$ For the purpose of this analysis, it is assumed that this does not happen.

\subsection{Justification and Proportionality}

\subsubsection{Safeguarding Coherence}

The first potential justification to be looked at is the safeguarding of coherence. ${ }^{55}$ Rust, for instance, thinks that denying deductibility for interest payments in the case of their tax exemption at the level of the recipient may be justified by this argument. ${ }^{56}$ The author has been hesitant to accept this reasoning in the context of the Hybrid Financial Instruments Rule because it does not achieve such coherence. ${ }^{57}$ Rather, it denies the deduction once an inclusion in the ordinary income is not given. ${ }^{58}$ This can be due to an exemption, but it can also be due to a special tax rate applying at, say, $10 \%$ instead of $20 \%$ because of some sort of different treatment. ${ }^{59}$ Aside from that, withholding taxes are not taken into account ${ }^{60}$ so what may be exempt (or lower taxed) may not really be so. Put more simply, the Hybrid Mismatch Rule does not ensure much coherence, and the Imported Mismatch Rule does so even less. ${ }^{61}$ Apart from that, it is understood that the ECJ requires a direct

\footnotetext{
${ }^{51}$ The structured arrangements rule should not apply to wholly domestic situations as there is no mismatch to be created.

52 As mentioned below in this section, the presence of withholding taxes - which are not taken into account in the context of the antihybrid rules - could mean that the tax outcome is ultimately not favourable. See, on the exclusion of withholding taxes, OECD BEPS Action 2, supra n. 2, at para. 407.

${ }^{53}$ Doubts on whether the ATAD does indeed promote the Internal Market and can thus can be based on Art. 115 of the Treaty on the Functioning of the European Union (TFEU) have been expressed in literature. See, e.g. A. de Graaf \& K.-J. Visser, ATA Directive: Some Observations Regarding Formal Aspects, 25(4) EC Tax Review (2016); G. Bizioli, Taking EU Fundamental Freedoms Seriously: Does the Anti-Tax Avoidance Directive Take Precedence over the Single Market?, 26(3) EC Tax Review 167 (2017); I. Lazarov \& S. Govind, Carpet-Bombing Tax Avoidance in Europe: Examining the Validity of the ATAD Under EU Law, 47(10) Intertax (2019); F. Oppel, BEPS in Europa: (Schein-) Harmonisierung der Missbrauchsabwehr durch neue Richtlinie 2016/1164 mit Nebenwirkungen, 25 Internationales Steuerrecht 797-799 (2016); and C. Staringer, Die Anti-Tax-Avoidance-Richtlinie:

Gesamtwürdigung aus steuerpolitischer Sicht, in: Die Anti-Tax-Avoidance-Richtlinie 1, 11 et seq. (M. Lang et al. eds., Linde 2017). Regarding Art. 115 TFEU being an adequate legal basis, see, e.g. N. Braun-Binder, Rechtsangleichung in der EU im Bereich der direkten Steuern 92-94 (Mohr Siebek 2017); and R. Szudoczky, The relationship between primary, secondary and national law, in: Research Handbook on European Union Taxation Law sec. 3.2. (C. H.J.I. Panayi, W. Haslehner \& E. Traversa eds., Edward Elgar 2020). For an overview, see also G. Kofler, EU power to tax: Competences in the area of direct taxation, in: Die Anti-TaxAvoidance-Richtlinie sec. 2.2. (M. Lang et al. eds., Linde 2017). This article will touch upon the issue in sec. 3.3.3.

${ }^{54}$ Because then, the Rule does not violate the applicable fundamental freedom.

${ }^{55}$ See, for a discussion, Scherleitner, supra n. 1, at sec. 5.5.2.1.; and compare, e.g. Helminen, supra n. 44, at 334-335; A. Rust, BEPS Action 2: 2014 Deliverable - Neutralising the Effects of Hybrid Mismatch Arrangements and its Compatibility with the

Nondiscrimination Provisions in Tax Treaties and the Treaty on the Functioning of the European Union, 60(3) Brit. Tax Rev. 315 (2015); Mechtler, supra n. 11, at 170-171, 381-382; Kahlenberg \& Vogel, supra n. 45, at 299; and O. Milanin, Vereinbarkeit sog Linking Rules mit der Niederlassungs- und der Kapitalverkehrsfreiheit unter Berücksichtigung einer möglichen Rechtfertigung, insbesondere durch die Kohärenz des Steuersystems, 24(22) IStR 861, (2015).

${ }^{56}$ Rust, supra n. 55, at 315: '[I]t seems to be possible that the non-deductibility of interest payments may be justified to achieve the coherence of the tax system if the payments are tax exempt at the level of the recipient. The different treatment at the level of the payor can be justified by the fact that the treatment at the level of the recipient is different as well: the payments are not deductible at the level of the payor if they are exempt at the level of the recipient and they are deductible at the level of the payor if they are taxable at the level of the recipient.'

${ }^{57}$ Scherleitner, supra n. 1, at sec. 5.5.2.1.

${ }^{58}$ Ibid.

${ }^{59}$ For an illustration, see, e.g. the examples in OECD BEPS Action 2, supra n. 2, at 175-278.

${ }^{60}$ Ibid., at para. 407.

${ }^{61}$ For critics on BEPS Action 2 fully disregarding the actual tax burden, see, e.g. P. Harris, Neutralizing effects of hybrid mismatch arrangements, in: United Nations Handbook on Selected Issues in Protecting the Tax Base of Developing Countries 262-263 (A. Trepelkov, H. Tonino \& D. Halka eds., United Nations 2017).
} 
link to exist with respect to the same income and the same taxpayer. ${ }^{62}$ Doubts as to the potential of the coherence argument in the context of the direct mismatch rules (different taxpayer) can only grow in the context of the Imported Mismatch Rule (different income, and the taxpayer other than the one who receives the income from the taxpayer that is subject to the Imported Mismatch Rule) ${ }^{63}$ While the ECJ seems to have relaxed its requirements somewhat, ${ }^{64}$ it is aware of the risk that can come with softening the criteria for successfully invoking the coherence argument. If the Imported Mismatch Rule can be justified by achieving coherence, many other rules could pass the same test. ${ }^{65}$

\subsubsection{Combination of Balanced Allocation of Taxation Rights and/or Prevention of Abuse?}

Due to applying only with respect to mismatches that occur between related parties or that result from structured arrangements, Article 9 of the ATAD targets situations that are thought to be abusive. ${ }^{66}$ Yet, and mostly based on the absence of the possibility for taxpayers within the scope of the hybrid mismatch rules to provide for counterproof, ${ }^{67}$ the abuse justification on its own has not been regarded as having the potential to justify the hybrid mismatch rules as the proportionality criterion will not be fulfilled. ${ }^{68}$ That being said, the ECJ has accepted presumptions of abuse when the abuse justification was invoked together with another justification. ${ }^{69}$

In this regard, a justification based on the combination of safeguarding the balanced allocation of taxation rights and the prevention of abuse seems most interesting. This was accepted by the court, for example, in SGI (C-311/08). ${ }^{70}$ While the tax planning technique was different (transfer mispricing), the core concern was the same, i.e. profit shifting to a typically lower-taxed affiliate. In Hornbach (C-382/16) ${ }^{71}$ and Impresa Pizzarotti $(\mathrm{C}-558 / 19),{ }^{72}$ the same logic was confirmed even without having regard to the abuse principle but based on

\footnotetext{
${ }^{62}$ E.g. Helminen, supra n. 40, at sec. 2.3.5.

${ }^{63}$ Compare, in more detail, Scherleitner, supra n. 1, at sec. 5.5.2.1. See, with further references, e.g. Helminen, supra n. 44, at 334335; J. Bundgaard, Hybrid Financial Instruments in International Tax Law 258 (Kluwer Law International 2016); Mechtler, supra n. 11, at 170-171, 381-382; and C. Marchgraber, Tackling Deduction and Non-Inclusion Schemes - The Proposal of the European Commission, 54(4) Eur. Taxn. sec. 6, footnote 56 . 4 (2015). See also DE: ECJ, 26 Oct. 1999, Case C-294/97, Eurowings

Luftverkehrs AG v. Finanzamt Dortmund-Unna, ECLI:EU:C:1999:524, paras. 41-44; and, going further, Rust, supra n. 55, at 316317; and P. Benéitez Régil, BEPS Actions 2, 3 and 4 and the Fundamental Freedoms: Is There a Way Out?, 56(6) Eur. Taxn. sec. 2.2.1.1., (2016); and note FI: ECJ, 3 Oct. 2002, Case C-136/00, Rolf Dieter Danner, ECLI:EU:C:2002:558, para. 56; Panayi, supra n. 47, at ch. 3; and, similarly, Rust, supra n. 55, at 317.

${ }^{64}$ See, for a discussion, especially Brokelind \& Wattel, supra n. 27, at sec. 15.8.2., with reference to DE: ECJ, 17 Dec. 2015 , Case C388/14, Timac Agro Deutschland GmbH v. Finanzamt Sankt Augustin, ECLI:EU:C:2015:829, para. 41; and DE: ECJ, 30 June 2016, Max-Heinz Feilen v. Finanzamt Fulda, ECLI:EU:C:2016:496, para. 33, in which the direct link requirement was relaxed.

${ }^{65}$ On the conceptual problem of a too-generous understanding of the coherence justification giving Member States almost carte blanche to justify more or less everything by invoking this argument, see C. Staringer, Missbrauchsbekämpfung, Aufteilung der Besteuerungshoheit und Kohärenz in der Rechtsprechung des EuGH, in: Europäisches Steuerrecht 368 (M. Lang ed., DStJG Tagungsband 2018).

${ }^{66}$ G. Cooper, Some Thoughts on the OECD's Recommendation on Hybrid Mismatches, 69(6/7) Bull. Intl. Taxn. sec. 1., 2.3.4. (2015); and Scherleitner, supra n. 1, at sec. 5.4.2.2.

${ }^{67}$ Counterproof may be provided to fend off an allegation of being part of a structured arrangement. However, once a person falls within the scope of the rules, counterproof for not having acted abusively does not succeed.

${ }^{68}$ On dismissing the abuse justification also in the context of the anti-hybrid rules, see, e.g. Mechtler, supra n. 11, at 148, 173; and Panayi, supra n. 47, at ch. 3. Compare also Helminen, supra n. 44, at 332-333; Rust, supra n. 55, at 313-314; Parada, supra n. 11, at 336-337, 342; and, recently, e.g. DE: ECJ, 20 Dec. 2017, Joined Cases C-504/16 and C-613/16, Deister Holding AG and Juhler Holding A/S v. Bundeszentralamt für Steuern, ECLI:EU:C:2017:1009, paras. 70, 97. See also CFE ECJ Task Force, supra n. 34, at sec. 4. See also the discussion in A.P. Dourado, Aggressive Tax Planning in EU Law and in the Light of BEPS: The EC Recommendation on Aggressive Tax Planning and BEPS Actions 2 and 6, 34(1) Intertax sec. 2.3. (2015). See, for a further-going analysis of the ECJ's abuse doctrine, e.g. Brokelind \& Wattel, supra n. 27, at sec. 15.4.

${ }^{69}$ See, in more detail, Brokelind \& Wattel, supra n. 27, at sec. 15.5 .

${ }^{70}$ BE: ECJ, 21 Jan. 2010, Case C-311/08, Société de Gestion Industrielle SA (SGI) v. Belgian State, ECLI:EU:C:2010:26, para. 63 et seq.

${ }^{71}$ DE: ECJ, 31 May 2018, Case C-382/16, Hornbach-Baumarkt-AG v. Finanzamt Landau, ECLI:EU:C:2018:366, para. 51 et seq.

72 IT: ECJ, 8 Oct. 2020, Case C-558/19, Impresa Pizzarotti \& C SpA Italia Sucursala Cluj v. Agenţia Naţională de Administrare Fiscală - Direcţia Generală de Administrare a Marilor Contribuabili, ECLI:EU:C:2020:806, para. 32.
} 
ensuring the balanced allocation of taxation rights alone. ${ }^{73}$ It may be worth trying to extend some considerations made in these transfer pricing cases to the Imported Mismatch Rule.

To begin, it should be recalled that it is the Member States that allocate taxation rights among themselves. If the end result is balanced, the ECJ helps Member States uphold it. ${ }^{74}$ Thus, the first step in analysing the chances for the potential of the Imported Mismatch Rule to be justifiable on the grounds of it ensuring a balanced allocation of taxation rights must lie in demonstrating that it protects a legitimate tax claim. ${ }^{75}$

While this seems to be relatively straightforward in transfer pricing cases, it is not immediately clear with respect to any hybrid mismatch rule of the sort included in Article 9 of the ATAD. Does the denial of the deduction for a payment that is, for the essential reason of the involved states treating it differently in some way, not included in the ordinary income of the relevant taxpayer safeguard a valid taxation right of the source state of the payment? Could a state uphold this argument if it permits the deduction of the same payment to a resident subject to no or low taxation? Equally, does the inclusion of a payment in the ordinary income of a taxpayer based on its deductibility in the source state protect a legitimate tax claim? Could a state uphold this argumentation if it exempts dividends that its residents receive from shareholdings in companies resident in zero-tax jurisdictions? ${ }^{76}$ Furthermore, with disparities between Member States' tax systems being allowed and with no single taxation principle in sight, is there a reason for the legislator to get active just in this area while, at the same time, leaving double taxation resulting from differences in legal treatment unaddressed?

The author believes that the answer to this last question is 'yes'. This conception starts by observing that the whole trick of engaging in tax planning with hybrids lies in replicating payments to a tax haven without being forced to actually make a payment into a tax haven. ${ }^{77}$ Metaphorically speaking, to the extent there is a deduction/non-inclusion (D/NI) outcome covered by Article 9 of the ATAD, the tax base does not end up on a small island in the Caribbean; rather, it disappears into a fiscal black hole located in the no-man's-land between two states. In essence, a payment that leaves as, say, an interest payment to be taxable at the level of the non-resident taxpayer arrives in a different form in the other state. This change happens in the middle and causes the payment to trigger different - and better - tax consequences. The actual task of anti-hybrid rules lies in discovering these payments. Thus, they get the tax base back on the table and therefore ensure that there is $a$ taxation right to be allocated.

The way in which such a taxation right is then allocated among the involved states is a political question. Even though tax-systematic considerations can play a role in deciding who is to get the initial taxation right, it is not a strict precondition for the hybrid rules to fulfil their goal. Rather, getting the tax base back and distributing it are two different issues. The latter is - and has always been - a matter for Member States to settle themselves. ${ }^{78}$ This logic also applies with respect to the Imported Mismatch Rule. There is a deduction that, to some extent, ultimately disappears somewhere. The Imported Mismatch Rules recovers it, in this case leaving only one possible tax consequence, i.e. the denial of the deduction in the source state.

Note, however, that in order to be able to defend a measure based on the protection of the balanced allocation of taxation rights, it is also necessary to establish that the Member State has not actually elsewhere chosen to

\footnotetext{
73 The arm's length standard is, at least so far, the prevailing principle when it comes to the allocation of income between integrated companies. As such, and subject to the proportionality of the rule, Member States are allowed to protect themselves against taxpayers shifting income to lower-taxed affiliates (by deviating from arm's length pricing). Compare, in the context of transfer pricing, but with further-going conceptual arguments, J. Englisch, Rechtfertigungsmöglichkeiten, in: Europäisches Steuerrecht paras 7.227, 7.255 et seq. (H. Schaumburg \& J. Englisch eds., Otto Schmidt 2020). In the same way, it constitutes a remedy against Member States that, for tax competition purposes, may accept prices that deviate too strongly from this benchmark. See, most recently, the judgment in IE: GC, 15 July 2020, Cases T-778/16 and T-892/16, Apple, ECLI:EU:T:2020:338, para. 140 et seq., stating that the Commission is, based on Art. 107 TFEU, allowed to supervise the application of the arm's length principle in Member States that foresee the equal treatment of integrated companies and stand-alone companies.

${ }^{74}$ J. Kokott, Das Steuerrecht der Europäischen Union sec. 5(A), para. 21 (Beck 2018).

${ }^{75}$ Compare, in the context of transfer pricing, but with further-going conceptual arguments, Englisch, supra n. 73, at para. 7.227, 7.255 et seq.

${ }^{76}$ Harris, supra n. 61, at 302.

${ }^{77}$ Ibid., at sec. 5 .

${ }^{78}$ See, e.g. Helminen, supra n. 40, at sec. 1.7.2.; and Schön, supra n. 36, at sec. 6.3.2.
} 
abstain from taxing the income. ${ }^{79}$ This is a difficult question, the answer to which will likely depend on the perspective. It could be stated that a Member State that exempts a dividend is committed to exempting payments that are, according to this Member State's law, regarded as dividends. In other words, all payments that have this character are exempt. Similarly, when payments received by an entity with certain characteristics do not, from the perspective of the shareholder state, flow through to the shareholder, this state has simply decided not to recognize this income at the shareholder level before it is distributed. Likewise, business expenses are deductible regardless of their taxation at the level of the recipient, at least as long as the separate entity principle and the ability-to-pay principle play a role in this jurisdiction. ${ }^{80}$ What (unsurprisingly) remains is the outcome that this state decides, as the case may be, to exempt the income or allow its deduction. Should that perspective prevail, a justification based on ensuring the balanced allocation of taxation rights can never succeed. Ultimately, the rules always apply when a taxpayer triggers only the tax consequences foreseen in this jurisdiction.

However, another view can also be taken. On the one hand, it could be submitted that, in purely domestic situations, the hybrid rules foresee these outcomes as well. Based on this, one could argue that the Member State has not chosen to not tax the income. Yet, anti-hybrid rules normally do not apply in a domestic context. ${ }^{81}$ Therefore, this is merely a theoretical possibility and, thus, a weak position. On the other hand, and more sensibly, it could simply be accepted that argumentation focused only on the decisions made in one state is too narrow in this context. Those opposing the need to combat tax arbitrage with hybrids have always been able to hide behind the spirit of the law of one jurisdiction to justify their actions, ${ }^{82}$ and those who hold differently have necessarily ignored that because tax planning with hybrids precisely exploits this difference. ${ }^{83}$ What is escaped is the tax normally due in the other state. ${ }^{84}$ This position can be criticized for its circularity. Yet, this is just what this tax planning strategy aims to do. The taxation rights of Member States should be protectable against taxpayers' attempts to play states against each other. After all, one state loses. It can be better left to those involved to decide how to deal with this.

At this stage, the focus will be changed to the abuse element of the justification. In this regard, it seems, first of all, necessary to define which parts of the transaction are to be assessed in this context. Is it the transaction as a whole, or does the potential abuse (i.e. artificiality) lie in the terms of the transaction? In the author's view, the better reasons speak for the latter perspective. In fact, to the extent that a transaction is not genuine, it will not make it that far. Rather, based on other rules (most importantly, the implementation of the general antiabuse rule (GAAR) included in Article 6 of the $\mathrm{ATAD}^{85}$ and/or transfer pricing provisions) ${ }^{86}$ it will already

\footnotetext{
${ }^{79}$ Kokott, supra n. 74, at sec. 5(A), para. 21; NL: ECJ, 8 Nov. 2007, Case C-379/05, Amurta, ECLI:EU:C:2007:655, para. 59; and FR: ECJ, 10. May 2012, Case C-338/11, Santander Asset Management SGIIC, ECLI:EU:C:2012:286, paras. 47-48.

${ }^{80}$ This issue has already been discussed with further references and with respect to hybrid financial instruments in Scherleitner, supra n. 1, at sec. 8.4.1.2.

${ }^{81}$ Note, however, that there are apparently countries where this could even be possible. This is indicated, e.g. in the example in OECD BEPS Action 2, supra n. 2, at 213-216, which applies in a domestic context.

${ }^{82}$ Meaning, in essence, that they have argued against combating tax arbitrage because there has been compliance with the laws of all of the involved states.. See, e.g. H. David Rosenbloom, International Tax Arbitrage and the "International Tax System", 53(2) Tax

L. Rev. (2000); and further relevant literature quoted in Scherleitner, supra n. 1, at sec. 1.3.

${ }^{83}$ Compare, conceptually, e.g. R. S. Avi-Yonah, Commentary (Response to article by H. David Rosenbloom), 53(2) Tax L. Rev. (2000), and further relevant literature quoted in Scherleitner, supra n. 1, at sec. 1.3.

${ }^{84} \mathrm{In}$ allusion to the requirement of 'escaping the tax normally due' in the Member State invoking the justification. See, e.g. FI: ECJ, 18 July 2007, Case C-231/05, Oy AA, ECLI:EU:C:2007:439, para. 63.

${ }^{85}$ Art. 6 ATAD reads: ' 1 . For the purposes of calculating the corporate tax liability, a Member State shall ignore an arrangement or a series of arrangements which, having been put into place for the main purpose or one of the main purposes of obtaining a tax advantage that defeats the object or purpose of the applicable tax law, are not genuine having regard to all relevant facts and circumstances. An arrangement may comprise more than one step or part.

2. For the purposes of paragraph 1, an arrangement or a series thereof shall be regarded as non-genuine to the extent that they are not put into place for valid commercial reasons which reflect economic reality.

3. Where arrangements or a series thereof are ignored in accordance with paragraph 1 , the tax liability shall be calculated in accordance with national law.'

${ }^{86}$ See, e.g. the update to the OECD Transfer Pricing Guidelines via OECD, Transfer Pricing Guidance on Financial Transactions: Inclusive Framework on BEPS Actions 4, 8-10 (OECD Publishing, 2020) on the recharacterization of transactions.
} 
have been disregarded. What remain are transactions that were entered into for a genuine reason. ${ }^{87}$ However, this does not mean that their terms are also genuine. Taxpayers with a genuine reason to enter into the transaction may artificially change the setup (i.e. the structure of the cash flows or the involvement of entities with certain characteristics) in an effort to create a mismatch. In this regard, the artificial element is the mismatch and nothing else.

In an attempt to test whether such understanding could be followed by the ECJ, recourse should be had to more recent (and, apparently, less strict) case law. ${ }^{88}$ Based on $N$-Luxembourg (C-115/16), scholars observed that, for the purpose of recognizing artificiality, the court demands that the tax motive is one of the principal purposes of the taxpayer's action and that the tax benefit contradicts the object and purpose of the tax system. ${ }^{89}$ Arguably - and leaving the question of proportionality aside for the moment - Article 9 of the ATAD could be seen to apply in such a context. However, at this stage, it seems crucial to make an explicit distinction between direct hybrid rules, on the one hand, and the Imported Mismatch Rule, on the other.

With respect to direct mismatch rules,${ }^{90}$ it seems prudent to assume that the involved taxpayers knew that they triggered a mismatch at the outset. If they did not know this, it would not demand too much of them to find out that there was a mismatch. The tainted motive criterion is, thus, implicit in the rules. With regard to the object and purpose of the law, the problem is similar to what was discussed above. One must be prepared to go beyond a single-jurisdiction view. Once it is recognized that taxpayers engineer the transaction with a view to reach a mismatch, a reason can be found to say that there is interference with the object and purpose of both tax systems, seen in concert. Given that the abuse justification would be relied on together with the justification of safeguarding a balanced allocation of taxation rights and considering the nature of tax arbitrage, the author sees a reason for the court to take such a wider perspective. ${ }^{91}$

A more substantial issue arises in the context of the proportionality analysis. The court demands that taxpayers have the possibility to counter the abuse presumption enshrined in the rules. ${ }^{92}$ Yet, the content of this is not fully clear, and it especially depends on how far-reaching the Hornbach judgment turns out to be. Taken alone, $S G I$ offers a reading that favours the proportionality of direct hybrid mismatch rules. The necessity to give the taxpayer the opportunity to come back and show commercial reasons for its actions could be (and partly was) understood as the need to give the taxpayer the chance to show that, contrary to what was claimed by the tax authorities, in reality, it complied with the arm's length standard. ${ }^{93}$ Extending this to anti-hybrid rules would mean that they are proportional if the taxpayer can demonstrate that it actually did not trigger a mismatch. Once there is a mismatch, this counterproof, of course, cannot succeed.

The German court referring Hornbach to the ECJ asked for the interpretation of the term 'commercial reasons' used in the proportionality test in SGI. Interestingly, the ECJ accepted commercial reasons that did not comply with the arm's length standard but resulted precisely from the shareholding itself. ${ }^{94}$ In the context of hybrid rules, this would mean that taxpayers could fend off the application of the rules by establishing a commercial purpose of structuring the transaction in a certain way.

\footnotetext{
${ }^{87}$ In the case of hybrid financial instruments, this would, e.g. be the case when the instrument was entered into to satisfy a real financing need. See, going further in this respect, Scherleitner, supra n. 1, at ch. 8.

${ }^{88}$ DK: ECJ, 26 Feb. 2019, Joined Cases C-115/16, N Luxembourg 1, C- 118/16, X Denmark, C-119/16, C Danmark I and C-299/16, Z Denmark, ECLI:EU:C:2019:134; DK: ECJ, 26 Feb. 2019, Joined Cases C-116/16, T Danmark and C-117/16, Y Denmark Aps, ECLI:EU:C:2019:135.

${ }^{89}$ Englisch, supra n. 73, at para. 7.252. For a more detailed analysis of the genesis of the ECJ anti-abuse doctrine, see Brokelind \& Wattel, supra n. 27, at sec. 15.4 .

${ }^{90}$ I.e. Art. 9(1)(2) ATAD.

${ }^{91}$ For clarity, the author refrained from arguing that the object and purpose of combating such hybrid mismatches is introduced in Art. 9 ATAD. While this is true, it cannot be used to test this rule itself from the perspective of primary EU law.

${ }^{92}$ E.g. Hornbach Baumarkt $A G(\mathrm{C}-382 / 16)$, supra n. 71 , para. 48 et seq.

${ }^{93}$ For a discussion and relevant references, see CFE ECJ Task Force, Opinion Statement ECJ-TF 1/2019 on the ECJ Decision of 31 May 2018 in Hornbach-Baumarkt (Case C-382/16) Concerning the Application of Transfer Pricing Rules to Transactions between Resident and Non-Resident Associated Enterprises, 59(9) Eurn. Taxn., 446, 450 (2019).

${ }^{94}$ Hornbach Baumarkt $A G$ (Case C-382/16), supra n. 71, para. 51 et seq.
} 
Yet, there are two arguments that speak against such a consequence. First, some authors emphasize that the ECJ's stance in Hornbach is to be interpreted narrowly and should only apply to situations such as the one at hand in the underlying case. ${ }^{95}$ If that is true, the logic mentioned above that is deduced from SGI can still prevail.

Further, and somewhat philosophically, the value of a 'commercial reasons test' in the context of direct hybrid mismatches may be questioned. In fact, it is prudent to assume that transactions covered by the hybrid rules have a commercial reason; otherwise, they would be deterred by the mere existence of these rules. ${ }^{96}$ This also extends to hybrids that happen by accident because, in that case, the reaching of a mismatch is, by definition, not the goal. Thus, there will be a commercial reason available to justify the structuring of a transaction in a certain way. ${ }^{97}$ This may especially happen outside the standard cases that were in the minds of the drafters of BEPS Action 2. A minority shareholder may have a genuine interest in a financial instrument incorporating certain terms ${ }^{98}$ and, with hybrid entity mismatches seeming to be very frequent in a private equity context, it is fair to assume that commercial justifications will be available as well. At this stage, however, it may be questioned why the existence of a commercial justification demands that the D/NI outcome has to prevail. Those who really have commercial justification should not mind the transaction being subject to normal taxation. In direct mismatch situations, there is almost no better evidence for non-existent commercial reasons than a taxpayer arguing that, without the mismatch, it would not enter into the transaction. As will be seen in section 3.3.3, this is not the whole truth because, in the presence of disparities between tax systems, it can happen that the application of a direct anti-hybrid rule triggers a worse outcome for the taxpayer. However, this seems relatively easy to avoid without doing much harm in this context. ${ }^{99}$

Should the author be wrong - that is, should accepting commercial justifications to switch off the direct antihybrid rules in fact be required ${ }^{100}$ - care must be taken to not allow this carve-out to become self-defeating. If taxpayers can argue that they had a commercial purpose just because they entered into the arrangement (and thus implicitly show that they had reasons other than obtaining the mismatch), it would not take long for taxpayers to simply enter into transactions to show that they had commercial justification and to regain the mismatch. In this case, the cat would bite its own tail. Consequently, if a carve-out based on valid commercial reasons should be required, there would have to be reliance on different indicators. This would not seem easy when it is considered, as mentioned above, that, based on different rules, the transaction has to be genuine and at arm's length. ${ }^{101}$ As such, the commercial justification that would carve out the transaction from the direct hybrid rules would likely have to be found in the structuring of the cash flows or the use of the entity. Stated differently, there must a valid reason to, for instance, design an intra-group finance transaction in a way that also happens to result in a D/NI outcome. In an intra-group context, that appears to be exceptionally rare. ${ }^{102}$ Yet, even if such a reason exits, it is hard to see why the application of the Hybrid Financial Instruments Rule would interfere with the transaction just because it results in normal taxation. Certainly, tax rate differentials can make choosing debt or equity more attractive. ${ }^{103}$ Yet, considering taxes in this setting is not some sort of

\footnotetext{
${ }^{95}$ F. Hoffmann, Die Rs. Hornbach und der Begriff wirtschaftliche Gründe - eine historische Analyse, 28(15) IStR 580 (2019). Regarding this to be a possible interpretation, see, e.g. CFE ECJ Task Force, supra n. 93, at sec. 5. For a different opinion, see Englisch, supra n. 73, at para. 7.257.

${ }^{96}$ Which is also the implicit goal of BEPS Action 2. See OECD BEPS Action 2, supra n. 2, at para. 278; and, with further references, Scherleitner, supra n. 1, at sec. 2.6.

${ }^{97}$ For an analysis of non-tax reasons to employ hybrid financial instruments, see, with further references, Scherleitner, supra $\mathrm{n}$. 1, at sec. 5.2.2.; and De Boer \& Marres, supra n. 45, at sec. 2.6.

${ }^{98}$ See also, with further references, the discussion in Scherleitner, supra n. 1, at sec. 2.2.5.

${ }^{99}$ See also the relevant discussion in sec. 3.3.3.

${ }^{100}$ In this regard, it is worth noting that only minor commercial reasons would not suffice. See, e.g. PT: ECJ, 10 Nov. 2010, Case C126/10, Foggia, ECLI:EU:C:2011:718, para. 47. Apart from that, one would have to explore the interaction between Art. 9 and Art. 6 $\mathrm{ATAD}$, the latter of which contains a general anti-abuse rule that demands Member States to disregard non-genuine transactions. See, on the latter provision, e.g. Smit, supra n. 11, at sec. 12.5 .

${ }^{101}$ I.e. the national implementation of Art. 6 ATAD, as well as relevant transfer pricing provisions.

${ }^{102}$ Scherleitner, supra n. 1, at sec. 2.2.5.

${ }^{103}$ Unless other rules foresee a different result, intra-group interest is normally tax deductible at the level of the payer and taxed at the level of the receiver while intra-group dividends are non-deductible at the level of the payer and exempt at the level of the receiver. See, for a literature review, e.g. ibid., at sec. 2.1.
} 
disadvantage to which the application of the Hybrid Financial Instruments Rule leads. Rather, it is the standard in a world where, de facto, every serious tax system distinguishes between debt and equity. ${ }^{104}$ As a result, the author does not see any value in a 'commercial reasons' test. Rather, also from this perspective and in the author's view, it would, end up defeating the purpose of the direct anti-hybrid rules.

Consequently, the proportionality of the rules should be judged on other grounds, namely, their goal to neutralize mismatches. As long as they do not go beyond that, they should be regarded as proportional. Admittedly, this may not always hold true. As withholding taxes ${ }^{105}$ and the taxation of the distribution of hybrid entities do not play a role in the application of the hybrid rules, ${ }^{106}$ the ultimate outcome can be 'overkill'. ${ }^{107}$ This could result in problems in the proportionality analysis, especially when the ultimate tax burden is the same or even higher than it would be if there were an inclusion in the ordinary income. ${ }^{108}$ Still, it seems clear that, when testing proportionality, a rather objective approach should be used. ${ }^{109}$

In summary, this means that it is at least principally conceivable that direct hybrid mismatch rules may be justified and proportional. ${ }^{110}$ Yet, it may not be straightforward to extend this to the Imported Mismatch Rule. First, there will be a focus on a textbook example. Say there are three states, A, B, and C, only the latter of which has implemented rules based on Article 9 of the ATAD. Assume that A Co., resident in State A, enters into a transaction with its fully owned subsidiary, B Co., resident in State B which causes a mismatch. The payment that is deductible in State B at the level of B Co. is exempt in State A at the level of A Co. In the absence of anti-hybrid rules in these states, the result remains as it is. B Co. now grants a loan to its fully owned subsidiary, C Co., resident in State C. The interest is deductible in State C at the level of C Co. and included in the ordinary income at the level of B Co., and, therefore, the direct mismatch rules of State $\mathrm{C}$ do not take effect. Yet, because the payment that B Co. makes to A Co. is deductible at the level of the former, there is, but for a small spread, no tax base left in State B. Due to the mismatch, there is no taxation in State A. When A Co., B. Co. and C Co. collude to reach precisely this outcome, there is a clear case for State $\mathrm{C}$ to deny the deduction. In fact, this is no different from a direct mismatch between States A and C. If State C denies the deduction for direct mismatches, it should also deny it here. With respect to these sorts of transactions, the author does not see a reason to adapt anything said above to the context of direct mismatch rules. If they can be justified based on the combination of safeguarding a balanced allocation of taxation rights and the prevention of abuse, this justification should also apply under these circumstances.

However, even minor changes to this very standard setting can lead to a substantially different conclusion. What if there is no economic connection between the mismatch between A Co. and B Co., on the one hand, and the loan from B Co. to C Co., on the other? ${ }^{111}$ Does the bad faith assumed under Article 9 of the ATAD

\footnotetext{
${ }^{104} \mathrm{See}$, for a literature review on the impact of taxation in the financing process, ibid., at secs. 2.2.2.2., 2.2.3., 2.2.5.

${ }^{105}$ See, again, OECD BEPS Action 2, supra n. 2, at para. 407.

${ }^{106}$ Ibid., at para. 156.

${ }^{107}$ With respect to withholding taxes, see Cooper, supra $\mathrm{n}$. 66; and Harris, supra $\mathrm{n}$. 61. Discussing this from an intertaxpayer equity perspective, see Scherleitner, supra n. 1, at sec. 5.4.2.2.

${ }^{108}$ To substantiate this by means of an example, it may not be proportionate to deny the deduction for a payment due to it not being included at the level of the receiver at the ordinary rate of $15 \%$ even though the payment is subject to withholding tax of $15 \%$. Certainly, these are different tax claims, and the source state decided to allow a deduction and to levy a withholding tax. Still, it also decided not to apply its hybrid rules when there is no mismatch, and there is no mismatch when the recipient is taxed at $15 \%$. It is hard to see why it should matter that it is the source state and not the residence state that is responsible for this burden. Yet, this argumentation does not go far enough. Once the withholding tax is below the rate that would prevail if there were an inclusion in the ordinary income, it would no longer seem problematic for the source state to apply its hybrid rules for the sake of denying a deduction. After all, it is the non-inclusion in the ordinary income - and thus taxation below $15 \%$ - that triggers the hybrid rule. Based on that, it could be demanded that withholding tax should at least be taken into account when the taxation of the recipient is at or above the tax rate that would have prevailed in the case that inclusion in the ordinary income had taken place. For similar reasons, the taxation of the distributions of hybrid entities should also be adequately taken into account.

${ }^{109}$ I.e. taxpayers' motives should not be taken into account.

${ }^{110}$ Focusing on the Hybrid Financial Instruments Rule, with further references, but based on a much narrower elaboration, see Scherleitner, supra n. 1, at sec. 5.5.2.1.

${ }^{111}$ Meaning, in oversimplified terms, that the taxpayer triggering the Imported Mismatch Rule had no idea about this (bona fide) transaction being somewhere else in the group offset against a mismatch. While the legal connection of course exists, the economic one is only deemed to exist due to the intra-group (or structured arrangement) setting. As the author discussed elsewhere, there are reasons to doubt whether this presumption is always correct. See Scherleitner, supra n. 1, at secs. 5.4.5., 9.3.
} 
with respect to transactions within its scope automatically extend to C Co.? Can C Co. show commercial reasons to salvage the deductibility of the interest?

The issue becomes clearer when it is considered that the Imported Mismatch Rule also applies when there is another entity in between. Say that B Co. granted the loan to its fully owned subsidiary, D Co., resident in State D (with no hybrid rules). If D Co. grants a loan to C Co., this will trigger the Imported Mismatch Rule in State C. In fact, it is not even necessary that there is a loan between D Co. and C Co.; rather, every deductible payment that is made from C Co. to D Co. triggers the Imported Mismatch Rule. ${ }^{112}$

Factors could almost endlessly be added to the above example to show that this rule is really difficult to apply and that the economic connection between the mismatch and the payment covered by the Imported Mismatch Rule can, sometimes, be very minor or even non-existent. ${ }^{113}$ There may be further layers between the taxpayers that created the mismatch; the first involved EU company whose residence state did not regard it as such; and the Member State that did regard it as such and applied the Imported Mismatch Rule. Payments can happen in different periods, tax positions may turn out to be wrong, information may be unavailable and, more relevantly, the tax administrations of countries with no hybrid mismatch rules may be unwilling to use their scarce resources to help other countries in applying their rules. ${ }^{114}$

At this stage, it should be recalled that the ECJ is prepared to 'accept reasonable presumptive criteria which contribute to reasonable protection against BEPS, legal certainty and practicability for both tax authorities and taxpayers'. ${ }^{115}$ The Imported Mismatch Rule, however, does seem to live up to that. The problem is that the legal quality of the imported mismatch is always the same regardless of whether the situation is like that of the textbook example mentioned above or anything else. However, the abuse element involved in the covered transactions can be very different. While the textbook example is as abusive as a direct mismatch, this is not necessarily so (and is even unlikely) with respect to other instances in which the rule applies. Instead, it is quite conceivable that, relative to direct mismatches, the Imported Mismatch Rule will relatively often be triggered by accident. ${ }^{116}$

Hence, in the same way as in the context of direct mismatch rules, the Imported Mismatch Rule should also combat really abusive transactions by deterring them. Transactions covered by the rules may be discovered in the course of a tax audit without the taxpayer having had a genuine idea about there being a mismatch imported. Certainly, this does not automatically mean that it is wrong to neutralize the imported mismatch. However, it appears that the abuse justification is quite removed in this context. The deemed artificiality of the mismatch that is exported into a jurisdiction does not predetermine the artificiality of the Imported Mismatch Payment although, of course, it also does not rule out the missing genuineness of the payment. It must also not be forgotten that the taxpayer in the EU Member State that does not neutralize the mismatch but exports it into another Member State principally acts in line with EU law. ${ }^{117}$ It would not have even had an option to neutralize

\footnotetext{
${ }^{112}$ See, for a description, OECD BEPS Action 2, supra n. 2, at paras. 234-271. See, for a substantial critique on the Imported Mismatch Rule from the perspective of administrability, Scherleitner, supra n. 1, at sec. 5.4.5.

${ }^{113}$ See, e.g. the discussion and references provided for in ibid.

${ }^{114}$ See ibid., especially the reference to M. Schler, OECD vs D/NI: Ending Mismatches on Hybrid Instruments, Part 1, 75 Tax Notes Intl. 485, 494 (2014).

${ }^{115}$ Brokelind \& Wattel, supra n. 27, at sec. 15.5.

116 This can be substantiated with an example. While it is demanded that the taxpayer knew it, the author is not sure whether the taxpayer really knew that, say, a service fee paid to another group company imported a mismatch because one group company somewhere else contracted with a third party in a way that the first mentioned taxpayer's residence state regards it as being a structured arrangement while none of the other involved states see it similarly.. See also the discussion and references provided for in Scherleitner, supra n. 1, at sec. 5.4.5.

${ }^{117}$ Of course, the commission can intervene and launch an infringement procedure that may end in this Member State ultimately having to neutralize the mismatch itself because this is what the ATAD demands. This could, e.g. be the case with respect to rules like the Luxembourg 'acting together' safe harbour, discussed in sec. 2, which widely results in the application of the Imported Mismatch Rule and may be at odds with the ATAD. Note, however, that it is not clear from the outset that this rule really is in breach of the ATAD. While it is, of course, true per recital 28 ATAD II, that BEPS Action 2 should close interpretive gaps, it is also important to note that the ultimate purpose of the ATAD is the furthering of the internal market. Based on this, the 'acting together' rule as included in Art. 2(4)(2)(b) ATAD may be interpreted in different ways. Putting this discussion aside, the commission may not be able to do much in
} 
the mismatch itself. This argument is not valid if the transaction is part of an arrangement intentionally aimed at exploiting this opportunity. It would be valid, however, if it is not part of such an arrangement.

Given that secondary EU law is at stake, it is not possible to rule out that the ECJ accepts the Imported Mismatch Rule on grounds such as those discussed above. After all, the 2-year minimum holding period provided for in the Parent-Subsidiary Directive ${ }^{118}$ has also been accepted as a fixed anti-abuse typification. ${ }^{119}$ Yet, while the author, in principle, understands that there is a reason for the ECJ not to judge national law and secondary EU law in the same way, ${ }^{120}$ should the court want uphold the Imported Mismatch Rule, it seems that the time has come to consider new justifications. The old ones might no longer be fit in light of the paradigm change that has occurred in EU tax policy. ${ }^{121}$ Section 3.3.3 analyses this.

\subsubsection{A New Justification?}

The ECJ is always free to accept new justifications for infringements of the fundamental freedoms. ${ }^{122}$ In essence, this requires the measure to be justified by an overriding reason of public interest and to be proportionate..$^{123,124}$

Normally, this discussion takes the following form: A Member State that has a rule in place that causes forbidden discrimination or restriction is deemed to have taken action that harms the internal market. In essence, this is because there is interference with decision neutrality. The choice made by the taxpayer in the presence of the discriminatory or restrictive measure is assumed to be inferior compared to what would have been done in its absence. ${ }^{125}$ The Member State, however, has the option to justify this distortion with a legitimate reason. In this context, the Court takes the Member States' interests into account. As they are ultimately politically accountable for taxation, some balancing is considered necessary. ${ }^{126}$

Yet, in the context of the Imported Mismatch Rule, things are different. Here, it is the denial of the deduction - and thus the alleged restriction itself - that should promote the internal market. This means that the rule should lead to a decrease in distortions. If it does, the need for justification conceptually does not emerge. Alternatively, if it emanate due to the ECJ formally sticking to its approach when examining the existence of a restriction, it could be invoked as a justification. What is, prima facie, deemed to harm the internal market

\footnotetext{
the context of the structured arrangements rule. Here, it is conceivable that different interpretations prevail and reconcile with the ATAD.

${ }^{118}$ Council Directive 2011/96/EU of 30 November 2011 on the common system of taxation applicable in the case of parent companies and subsidiaries of different Member States, OJ L 345/8 (29 Dec. 2011).

${ }^{119}$ NL: ECJ, 17 Oct. 1996, Joined Cases C-283/94, C-291/94, C-292/94, Denkavit u.a, ECLI:EU:C:1996:387, para. 31, as addressed in Hey, supra n. 26, at 30.

${ }^{120}$ See the discussion and references provided for in sec. 3.1 .

${ }^{121}$ Apparently doubtful, see also Schön, supra n. 36, at sec. 6.3.4., who, in the case of inter alia hybrids, states: 'Under its current jurisprudence, the ECJ might require a restrictive interpretation of these directive provisions in line with its jurisprudence on abusive arrangements.'

${ }^{122}$ See, in more detail, e.g. Helminen, supra n. 40, at sec. 2.3.1.; or Englisch, supra n. 73, at para. 7.199 et seq.

${ }^{123}$ Compare ibid., and see, e.g. DE: ECJ, 20 Feb. 1979, Case C-120/78, Rewe Zentral AG v. Bundesmonopolverwaltung fur Branntwein (Cassis de Dijon), ECLI:EU:C:1979:42.

${ }^{124}$ Note that, already at this stage, as the author already discussed in Scherleitner, supra n. 1, at sec. 5.5.2.1., he cannot follow the view of scholars who argued that the ECJ could accept hybrid rules based on them ensuring single taxation. It is, in principle, not up the ECJ to allocate taxation rights between Member States, and accepting something like a single taxation principle in the context of the antihybrid rules could have undesired effects when it comes to issues of double taxation. Thus, this argument is not followed in this article. ${ }^{125}$ See W. Schön, Neutrality and Territoriality - Competing or Converging Concepts in European Tax Law?, 69(4/5) Bull. Intl. Taxn. sec. 1 (2015), based on the prohibition of Member States from taking any action that is likely to 'deter', 'discourage', or 'dissuade' economic actors from moving freely within the confines of the European Union, as expressed, e.g. in Verkooijen (Case C35/98), supra n. 38, at para. 34; BE: ECJ, 21 Jan. 2010, Case C-311/08, Société de Gestion Industrielle SA (SGI) v. Belgian State, ECLI:EU:C:2010:26, para. 50; and DK: ECJ, 17 July 2014, Case C-48/13, Nordea Bank Danmark A/S v. Skatteministeriet, ECLI:EU:C:2014:2087, para. 22.

${ }^{126}$ See, e.g. Englisch, supra n. 73, at para. 7.203; F. Vanistendael, The functioning of fundamental freedoms and tax neutrality in the internal market, in: Research Handbook on European Union Taxation Law (C.H.J.I.C. Panayi, W. Haslehner \& E. Traversa eds., Edward Elgar 2020).
} 
would be justified due to it actually helping it. ${ }^{127}$ The key question, thus, is: Now tell us, Imported Mismatch Rule, how do you feel about the internal market? ${ }^{128}$

The discussion in section 3.3.2 indicated that it is realistic for the Imported Mismatch Rule to be triggered by accident. If that happens, it would come up in a tax audit. The consequence is an adjustment of the taxable income plus, as the case may be, interest and penalties. Even though this is an unpleasant surprise for the taxpayer, this event is neutral from the perspective of the internal market. ${ }^{129}$ The decision of the taxpayer in this case was, per definition, not influenced by tax considerations. Thus, there was no suboptimal choice that was neutralized by the Imported Mismatch Rule nor did the rule cause a suboptimal restructuring behaviour.

The more interesting question occurs now: What does the taxpayer do once it is known that an envisaged genuine transaction triggers the Imported Mismatch Rule? The answer should be: nothing. However, the author has serious doubts as to whether this really happens. It is very well possible that the taxpayer reacts and restructures its affairs with the aim to not trigger this rule. Where, when, and whether this happens depends on the facts of the underlying case. To see how easily it can happen, consider the following: 'No inclusion in the ordinary income' does not mean that the payment needs to be exempt. Rather, it just means that there is some sort of different tax treatment. This could be an unreasonably long time difference, the applicability of a reduced rate, special relief, ${ }^{130}$ or anything that results from the establishment jurisdiction of an entity allocating the payment received by the entity to an investor whose residence state ignores the effect of this attribution. ${ }^{131}$ Most importantly, the actual tax liability does not matter. When the difference in tax treatment leads to taxation at a special rate of, say, $17 \%$ instead of the ordinary rate of $20 \%$, the payment is seen as not being included in the ordinary income. At the same time, when it is included in an ordinary tax base of $5 \%$, the hybrid rules remain untriggered. ${ }^{132}$ As mentioned, withholding taxes or the taxation of later distributions from a hybrid entity do not count in this regard. ${ }^{133}$ However, all of that matters to the taxpayer.

Thus, as long as disparities between tax systems exist, it is possible - and may even occur frequently - that taxpayers will react to the Imported Mismatch Rule. The deduction that would be denied under the rule may be more valuable than the missing inclusion in the ordinary income, especially because the latter can, as just

\footnotetext{
${ }^{127}$ Note that this would not be a substantially new approach per se as similar considerations may also occur in instances in which the abuse justification is invoked alone. Also here, a rule can be found restrictive but be justified due to targeting only wholly artificial arrangements which, in line with safeguarding the legitimate interest of a Member State to protect itself against abusive practices, can also be argued to promote the internal market. After all, such non-genuine arrangements distort the optimal resource allocation, too. See, on the latter, e.g. European Commission, Communication from the Commission to the European Parliament and the Council, Anti-Tax Avoidance Package: Next Steps Towards Delivering Effective Taxation and Greater Tax Transparency in the EU, $\operatorname{COM}(2016) 23$ final, 2 (28 Jan. 2016); and compare the discussion in Schön, supra n. 36, at 286, 288. Yet, this issue is more difficult than what can be discussed here, especially because it is unclear as to what extent the fundamental freedoms cover non-genuine arrangements. See, going further, e.g. Englisch, supra n. 73, at paras. 7.251-7252. Aside from that, based on Art. 6 ATAD, wholly artificial arrangements would have to be ignored. Provided that this rule is applied in the same manner in cross-border and domestic contexts, the need for justification does not emerge even if the arrangement is covered by the fundamental freedoms. See, similarly, with respect to the German GAAR, Englisch, supra n. 73; and compare, going further, Schön, supra n. 36, at sec. 6.4. Leaving all of that open here, in the context of this article, real payments are at stake as these are what the Imported Mismatch Rule applies to. ${ }^{128}$ Leaning on Johann Wolfgang von Goethe, Faust I, Vers 3415 (1829) including the famous Gretchenfrage which is, in rough terms, understood as a question going to the core of the issue and that the one being asked does like to answer.

${ }^{129}$ Of course, the mere tax payment also has, by itself, an indirect effect on welfare which amounts to the difference between the welfare effects that tax creates at the level of the government and the welfare effects it would have triggered had it still been available to the taxpayer.

${ }^{130}$ See, in more detail, OECD BEPS Action 2, supra n. 2, at paras. 29-60.

${ }^{131}$ See ibid., at para. 140, and note that this wording can cover numerous instances that might not have been considered. Without further elaborating on this, it should be mentioned that this is frequently an issue in the context of investment partnerships in which investors may not have received the necessary information to calculate their tax liability on a flow-through basis even though they are supposed to do so. Countries deal differently with such problems but all can lead to the end result of the establishment state's allocation of the income to the investor being ignored. See also the critique expressed in Harris, supra n. 61, at sec. 2.3.2.2., who states: "“T] $]$ reated as a separate entity" and "transparent" are not defined in OECD BEPS Action 2, supra n. 2, Inevitably, these terms will give rise to difficult issues. They are terms used by tax administrators and professionals, but they are really the opposite ends of a spectrum rather than absolutes.'

${ }^{132}$ See, on the ignorance of the actual tax burden in BEPS Action 2, e.g. Scherleitner, supra n. 1, at sec. 5.4.2.1.; Harris, supra n. 61, at sec. 3.1.1.; or Schler, supra n. 114, at 491-492, 496.

${ }^{133}$ E.g. ibid.
} 
shown, be of little value. Such restructuring thus just happens in order to avoid the application of the Imported Mismatch Rule. This is inefficient and does not promote the internal market.

Intervention can now occur, and it can be stressed that this is precisely what it is about. Ultimately, there is no mismatch imported, so the anti-hybrid rules have reached their goal. However, this intervention would not be correct. In fact, the anti-hybrid rules only aim to deter transactions that intend to obtain the mismatch and to leave in peace those that do not. In both cases, this should be reached by taking the tax benefit away. In this way, those looking for the benefit will not avail of it, and those who are not will be okay with it being absent. However, the anti-hybrid rules should not trigger the restructuring of an otherwise optimal transaction pattern. Yet, as mentioned in section 3.3.2, this can already happen in the context of the direct mismatch rules whereby, however, the negative impact on efficiency may be minimal. Say that the optimal financial instrument to cater to the needs of two related parties happens to be a debt/equity hybrid that causes a D/NI result. ${ }^{134}$ If that took place within the EU, the consequence would be the denial of the dividend exemption and thus taxation in the residence state. If that is unfavourable because the tax in the residence state is higher than the tax in the source state, the taxpayers, being aware of this, will restructure the instrument to be equity in both states. If it is the other way around (i.e. it is favourable because the tax is higher in the source state than the residence state), they will restructure it to be debt in both states. While there is efficiency loss, ${ }^{135}$ it might be very small given that, in an intra-group context, non-tax considerations for financing with debt or equity are typically considered rather minor. ${ }^{136}$ Likewise, while triggering anti-hybrid rules in fund structures can easily happen, it is also possible to have investors that otherwise effectuate the anti-hybrid rules investing via a feeder vehicle that switches off the hybrid rules. ${ }^{137}$ Of course, this is not optimal. Nonetheless, it must not be forgotten that the deterrence of purely tax-motivated mismatches also incorporates substantial efficiency gains even if they cannot be seen. Thus, on balance, it seems that efficiency gains may very well exceed efficiency losses triggered by the direct mismatch rules. ${ }^{138}$

In the context of the Imported Mismatch Rule, it is essentially the same balancing exercise. On the one hand, there are, undoubtedly, efficiency gains due to purely tax-motivated transactions being deterred. On the other hand, taxpayers may adapt genuine transactions in order not to trigger the Imported Mismatch Rule. The risk of falling within the scope of the rule is omnipresent. In fact, whenever there is no connection between the mismatch and the payment triggering the Imported Mismatch Rule and provided that the recognized mismatch prevails, such behaviour can take place. Given that the Imported Mismatch Rule applies to all deductible payments and noting that the mismatch could have occurred somewhere in the group, the potential for inefficient adaptions is especially great.

However, with all of that being said, it still needs to be remembered that the application of the Imported Mismatch Rule in an intra-EU context remains exceptional. As mentioned in section 2, there are some areas that are prone to triggering it but, normally, the inefficiencies mentioned above occur with respect to payments made to third countries. Thus, it appears fair to believe that, at least within the EU, the positive effects of the Imported Mismatch Rule may prevail. ${ }^{139}$

This would leave open the question of proportionality. The Imported Mismatch Rule must be appropriate to obtain its objective of promoting the internal market, and it must not go beyond that goal. ${ }^{140}$ As indicated just above, the rule promotes the internal market, but this comes at a cost, i.e. parts of the Imported Mismatch Rule can harm it. Apart from the extraordinarily high compliance and administration costs, this concerns the

\footnotetext{
${ }^{134}$ E.g. because it is deductible in the source state but exempt as a dividend in the residence state.

${ }^{135}$ See the discussion in Scherleitner, supra n. 1, at sec. 5.4.4.1.

${ }^{136}$ In more detail and with further references on this issue, see, e.g. ibid., at sec. 2.2.5.

${ }^{137}$ See also Cabollet, supra n. 16, at sec. 4.1.

${ }^{138}$ Focusing on the Hybrid Financial Instruments Rule in more detail and with further references, see, e.g. Scherleitner, supra n. 1, at sec. 5.4.4.

${ }^{139}$ Provided, notably, that the Imported Mismatch Rule can indeed be credibly administered. If that is not the case, different considerations apply. See, going further, Scherleitner, supra n. 1, at secs. 5.4.5., 9.2.

140 On proportionality, see, e.g. Helminen, supra n. 40, at sec. 2.2.5.; and Englisch, supra n. 73, at para. 7.205 et seq.
} 
inefficient restructuring of genuine transactions in order to avoid triggering the rule. Against this background, it seems that there are several perspectives from which the issue can be examined.

First, the Imported Mismatch Rule can be considered as a package. The desired deterrent effect cannot be achieved without such an administratively challenging rule at hand that can (really) ${ }^{141}$ be invoked should it be necessary. The fact that the presence of this rule can lead to inefficient responses from the taxpayer is, although triggered by it, ultimately not attributable to Imported Mismatch Rule. Rather, it is the result of disparities between tax systems that still exist. This would result in a similar problem as described above. While the Imported Mismatch Rule denies the deduction only to the extent that the payment directly or indirectly funds a hybrid mismatch, the rule still ignores withholding taxes and the taxation of later distributions. Thus, in the context of the mismatch imported, it could be that the relevant taxpayer even suffers consequences that are the same as or even worse than those that would have occurred had there been an inclusion in the ordinary income. ${ }^{142}$ Consequently, some uncertainty seems to lie in this question as well.

Second, a broader perspective could also be taken. In fact, anti-hybrid rules are just a tiny part of a Member State's arsenal of anti-abuse rules. Their task is to neutralize mismatches that occur based on the different treatment of a transaction in the affected states. Thus, conceptually, anti-hybrid rules back up a state's approach against payments made to non/low-taxed recipients, and the Imported Mismatch Rule backs up these rules as well. ${ }^{143}$ In essence, taxpayers should be denied the possibility to replicate payments made to tax havens by using states with 'decent' ${ }^{\prime}$ t4 tax systems. At this stage, readers should ask themselves how their home jurisdiction deals with low taxation imported from a tax haven. In the case of State $\mathrm{C}$ in the example in section 3.3.2, would it deny the deduction because B Co. made a payment to a non/low-tax jurisdiction? If so, would it do the same if there are several additional companies in between? Conceivably, the GAAR of State C could apply in this situation provided, in rough terms, that everything was indeed the plan of the involved taxpayers. ${ }^{145}$ However, it seems that, in practice, the application of such a provision is nearly impossible. ${ }^{146}$ Thus, it could be that replicating the results that the Imported Mismatch Rule tries to combat is not too difficult. It suffices that one group member makes a payment to another group company that is non/low-taxed. Notably, it is not necessary for this to be a group company in a tax haven. It can also be that the group company, say, enjoys a temporal tax holiday. In this regard, problems with respect to proportionality could arise because it may be argued that the legislator does not take the promotion of the internal market by denying imported mismatches seriously enough if it also does not address such replications. Thus, only ill-advised taxpayers tap into the rule while well-advised taxpayers may import the no/low-tax result by different means. ${ }^{147}$ However, those who support this argument should be asked how they would judge the proportionality of direct mismatch rules in the absence of an Imported Mismatch Rule. The former would become pointless in the absence of the latter. Unless states are prepared to overcome the root of the problem - that is, divergent tax systems - this may simply have to be endured.

If all of what was held in this section is true, there is still one very difficult question that remains. What if - as is likely to occur - a case being escalated to the ECJ is one that involves an imported mismatch that was discovered in the context of a tax audit without taxpayers having had an idea about it? ${ }^{148}$ In such a case, the Imported Mismatch Rule, by definition, does not promote the internal market, yet it also does not harm it. However, can also the latter be a justification? Maybe the author's cat has bitten its own tail now, ${ }^{149}$ and maybe this question should indeed be solved by testing the existence (or non-existence) of a restriction.

\footnotetext{
${ }^{141}$ Again, the deterrent effect may disappear if the rules ultimately turn out to be non-administrable.

${ }^{142}$ See the discussion in supra sec. 3.3.2.

${ }^{143} \mathrm{See}$, in this regard, the discussion and references provided for in Scherleitner, supra $\mathrm{n} .1$, at sec. 1.3.

${ }^{144}$ Harris, supra n. 61, at sec. 5 .

${ }^{145}$ Compare, for a somewhat similar discussion, Scherleitner, supra n. 1, at sec. 9.3.

${ }^{146}$ Compare the discussion in Scherleitner, supra n. 1, at sec. 8.4.1.2.

${ }^{147}$ For the logic underlying this thought, compare, in a different context, P. Wattel, Conceptual Background of CJEU Case Law in

Direct Tax Matters, in: European Tax Law 633 (P. Wattel, O. Marres \& H. Vermeulen eds., Wolters Kluwer 2019).

${ }^{148}$ Whether they should have had an idea about it is not relevant for this argument.

149 The author thanks his cat for inspiration.
} 


\section{Conclusion}

While it is not what the drafters of BEPS Action 2 and, thereafter, Article 9 of the ATAD wanted to see, some differences between Member States' application of the anti-hybrid rules have been spotted or are to be expected. Thus, the national implementation of the Imported Mismatch Rule contained in Article 9(3) of the ATAD can be triggered with respect to intra-EU payments. Against this background, the author analysed the Imported Mismatch Rule in light of the fundamental freedoms.

Other than initially expected, it has proven to be very difficult to extend the author's considerations made in the context of direct mismatch rules ${ }^{150}$ to the Imported Mismatch Rule. Even though the former cannot work without the latter, the latter may be too different from the former to allow the ECJ to see a (potential) restriction justified by the existing canon of accepted justifications in the direct tax field. Certainly, as secondary EU law is at stake, it cannot be ruled out that the court applies a more lenient approach. Yet, maybe the time has come for the ECJ to take a stance on whether it is willing to accompany the paradigm change in EU tax legislation with a paradigm change in jurisprudence.

The issues discussed in this article are no more than a tiny example of what may come up in the future. ${ }^{151}$ Readers should keep in mind that the international tax system is in the middle of being reshaped. Should the EU, as the author has urged elsewhere, ${ }^{152}$ decide to implement a minimum taxation system, it would be a core requirement for the relevant legal act to promote the internal market. The author would not be surprised if the discussion of these rules from the perspective of the fundamental freedoms would take a similar form as what was included in this article, hopefully resulting in commentators finding clearer answers than this author has found.

\footnotetext{
${ }^{150}$ See the author's analysis made in the context of the Hybrid Financial Instruments Rule in Scherleitner, supra n. 1, at sec. 5.5.2.1.

${ }^{151}$ See, for a broader perspective, especially Schön, supra n. 36.

${ }^{152}$ M. Scherleitner, Should the EU implement a minimum taxation regime?, Helsinki Legal Studies Research Paper No. 62 (25 Aug. 2020).
} 